\title{
Culture Approach as Innovation in Development of Infrastructure
}

\author{
Azima Dimyati \\ Faculty of Social and Political Science, Universitas Bandar Lampung \\ Selvi Diana Meilinda \\ Faculty of Social and Political Science, Universitas Bandar Lampung \\ Fikri M. Akbar \\ Faculty of Social and Political Science, Universitas Bandar Lampung
}

\begin{abstract}
The cultural approach to implementing public infrastructure policies is new. The approaches commonly used in implementing policies are structural approaches (organizational roles), procedural and management approaches (network planning and control; program evaluation and review techniques), behavioral approaches: communication, complete information at each stage and a political approach (interdepartemental aspects of politics). This shows that, the cultural approach is an innovation of policy implementation to establish a model of policy implementation innovation with a cultural approach, researchers investigate in a case study of a simultaneous village building program (GSM) in the Tulang Bawang regency of Lampung Province. This study uses a qualitative approach that describes and explains the symptoms and trends in phenomena that appear at the research location. The results obtained, the implementation of the GSMK program is based on the value of mutual cooperation which in local terms Lampung is called sakai sambayan. Sakai Sambayan, covering a broad understanding, such as mutual cooperation, help to help, tolerance to others and to others both morally and materially at times of pleasure and distress. This value provides a spirit in the implementation of the GSMK program in Tulang Bawang Regency. The GSMK program is a movement carried out by, from, and for the people of Tulang Bawang Regency to do good together in an effort to accelerate infrastructure development in 147 villages simultaneously throughout the Tulang Bawang Regency with a budget sourced from nongovernment organizations, private parties from each village and Community Direct Assistance (BLM) of the APBD of Tulang Bawang Regency. This program is considered quite successful by many people, the innovation of cultural approaches in the implementation of policies makes it an alternative so that policies can be successful and goals can be achieved.
\end{abstract}

Keywords: Cultural Approaches; Innovation; Implementation of infrastructure programs

DOI: $10.7176 /$ PPAR/9-9-07

Publication date:September $30^{\text {th }} 2019$

\section{INTRODUCTION}

The cultural approach in implementing public policy is new. The approaches commonly used in implementing policies are structural approaches (organizational roles), procedural and management approaches (network planning and control / npc; program evaluation and review technique / pert), behavioral approaches: communication, complete information at each stage, and a political approach (interdepartemental aspects of politics). This shows that the cultural approach is an innovation in policy implementation. To be able to establish a model of policy implementation innovation with a cultural approach, researchers will investigate in a case study of the Program Gerakan Serentak Membangun Kampung (GSMK) in the Tulang Bawang Regency of Lampung Province. Program Gerakan Serentak Membangun Kampung (GSMK) is one of the flagship programs of the Tulang Bawang District Government which is a model for all villages in Indonesia. This program was implemented before the village law.

The purpose of this program is an effort of the Tulang Bawang Regency Government to encourage the development program by, from, and for the community to take advantage of the unique social potential and institutions in Tulang Bawang, by providing direct financial assistance as a stimulant to the village community. Previously, the results of research on this program stated that during the planning, implementation, monitoring and evaluation stages it was found that in the majority of villages the majority of which were native occupations the community was less involved in planning activities so that the implementation stage was not in accordance with what the community wanted. But it is different from the village where the majority of the population is migrants, they are very enthusiastic in running the GSMK program. As well as in the case of lack of supervision by the government on the implementation of the GSMK program / cause the results are not in accordance with what is expected by the Government. The results of this study indicate there is a cultural influence in its implementation, this will contribute to the model that will be made later. 


\section{RESEARCH METHODS}

This study uses a qualitative approach that describes and explains the symptoms and trends in phenomena that appear at the research location. Data collected in the field are qualitative data in the form of words and behaviors, sentences, schemes, and images (Moleong, 2000). This approach is used to examine objects in natural conditions, where researchers are key instruments with data collection techniques carried out in triangulation (combined), inductive data analysis and research results that emphasize the meaning rather than generalization (Sugiyono, 2003), in order to get a complete picture of policy implementation innovation through a cultural value approach, especially in the GSMK program.

\section{III.RESULTS AND DISCUSSION}

\section{A. Simultaneous Movement Program to Build Villages}

The Village Development Simultaneous Movement Program (GSMK) is the flagship program of the Tulang Bawang Regent, Ir. Hi Hanan A. Rozak, MS and Deputy Regent of Tulang Bawang Heri Wardoyo, SH. The GSMK program, which has been running since 2013 and is planned to be implemented within a period of 5 (five) years (2013-2017), is carried out annually in accordance with the budget year of the activities of the Tulang Bawang Regency Government.

The GSMK program is a movement carried out by, from, and for the people of Tulang Bawang Regency to do good together in an effort to accelerate infrastructure development in 147 villages simultaneously throughout the Tulang Bawang Regency with a budget sourced from non-government organizations, private parties from each village and Bantuan Langsung Masyarakat (BLM) of the APBD of Tulang Bawang Regency.

As stated in the Tulang Bawang Regent's Regulation on the GSMK Program, the purpose of the GSMK Program is an effort by the Tulang Bawang Regency Government to encourage the development program from, by and for the community by utilizing the unique social potential and institutions in Tulang Bawang Regency, with provide direct funding assistance as a stimulant to the community for the construction of facilities and infrastructure (infrastructure) that are needed and useful for the community.

Before the issuance of Law No. 06 of 2014 concerning Villages, the GSMK program has begun to be implemented with a budget sourced from the Tulang Bawang District Budget amounting to Rp 200 million per village each year. However, since the adoption of Law No. 06 of 2014 concerning Villages, starting in 2015 the GSMK budget was included in the Alokasi Dana Desa (ADD) and increased to Rp 225 million per village each year from the APDB and ABPD village funds from the Tulang Bawang Regency.

The purpose of the implementation of the GSMK program is to be able to increase the participation of rural communities in regional development through community empowerment activities and the process of learning democracy in development. In addition, this program is aimed at increasing the self-help of rural communities in the implementation and preservation of development, increasing the spirit of mutual cooperation and togetherness in carrying out the development process and accelerating the development of facilities and infrastructure in the village so that it can create a sense of belonging to the urban community towards the results of development.

The GSMK funds are directly allocated to the village community in the amount of Rp.225 million through three phases, namely stage I disbursement of $40 \%$, stage II disbursement of $40 \%$ and stage III disbursement of $20 \%$ with funds managed by Community Groups (Pokmas) accompanied by the District Facilitators. Pokmas is the chief technical executive who is formed by the village community through village meetings involving local community leaders and leaders. In addition to Pokmas, in the management of the GSMK funds, the village is also assisted by facilitators chosen by the kecamatan to assist the village.

The results of the Village Conference (Muskam) in the form of an agreement on the infrastructure to be built using the GSMK funds were submitted to the Regional Government. The workshop involved Pokmas, Village Apparatus, GSMK Facilitators and community leaders. The purpose of Muskam is to establish any infrastructure development agreements that are urgently needed by the village to get the Regent's approval.

As stipulated by the Regent's Regulation on GSMK, infrastructure development includes construction of offshore roads, construction of bridges, construction of penetration pavement, construction of tertiary irrigation channels, construction of taluds, construction of paving blocks, and construction of boreholes. This development was monitored by the District Coordination and Coordination Team and Sub-district Facilitators, which further progress was reported to the Regent of the GSMK.

The specialty of the GSMK program is the appreciation of the best villages that can manage GSMK funds efficiently. This form of assessment is in the form of physical development between planning and realization in the field. There were three best village awards in each sub-district, each village that received the first prize won an additional fund of $\mathrm{Rp}$. 50 million, the second winner received an additional Rp. 30 million, and the third winner received an additional Rp. 20 million. Then the funds were given to the GSMK disbursement the following year. Another feature that distinguishes the GSK program from the PNPN program or other programs is that the GSMK program has been realized before the policy on village fund allocation began to be 
implemented after the Law No. 06 of 2014 concerning Village. This means that the GSMK program was raised with the courage of the Tulang Bawang Regency Government to cut its APBD funds in a very large amount to be transferred to the implementation of the GSMK program.

In addition, each village has the responsibility of reporting at the end of the GSMK activities. These reports are in the form of progress reports on activities and use of funds in phase I, including documentation of physical progress conditions of at least $50 \%$ (requirements for disbursement II), progress report II and use of phase II funds, including documentation of physical progress conditions of at least $80 \%$ (requirements for disbursement III), the final report and accountability letter for the use of funds and $100 \%$ documentation.

\section{B. Cultural Conditions in Tulang Bawang Regency}

Tulang Bawang Regency was formed on March 20, 1997. But in 2008 Tulang Bawang District was divided into three new autonomous regions (DOB), namely Tulang Bawang Regency, Tulang Bawang Barat Regency, and Mesuji Regency. The original inhabitants of Tulang Bawang Regency are Lampung Pepadun tribe with the clan known as Megou Pak Tulang Bawang (Four Marga Tulang Bawang). In addition, the accent is used in the everyday language of the indigenous people of Tulang Bawang, namely accents using the dialect "O".

Characteristics of the Lampung Tulang Bawang indigenous population, including living in groups to form villages with settled patterns, some are on the banks and banks of the river with a permanent pattern and some are not settled. Do not settle in question, among other things, their place of residence is only occupied at certain times, such as during the planting season or fishing.

The basic principles of Lampung people in everyday life show a distinctive style that is typical of the Lampung native population. Especially for the people of menggala which are arranged as follows:

1. Pi'il pesenggiri which means everything that concerns the self-esteem of behavior and attitudes that can maintain, uphold the good name of personal dignity and in a group that is always maintained.

2. Sakai Sambayan, covering a broad understanding, such as mutual cooperation, helping to help, tolerance towards others and towards others both morally and materially at times of pleasure and distress.

3. Meet nyimah which means respect and generosity to guests.

4. Nengah nyapur is as a system of life for the people of Lampung, especially in socializing and socializing, participating in constructive activities.

5. Bejuluk beadek is a nickname at a time which is certainly based on the gematei titei (rules or ways that are in accordance with the traditional law of the people of Lampung) that was passed down from ancient times.

But now the population of Tulang Bawang Regency is dominated by migrants from Java, Sunda and Bali, with the main livelihoods being rubber, oil palm and farming. Because it is dominated by Javanese, Sundanese and Balinese migrants, the majority of religions are Islam and Hinduism. But the most dominant tribe is Javanese, so Javanese is very commonly used by the population as a common language. However, with the diversity of tribes living in the Tulang Bawang Regency, it does not detract from the togetherness of its citizens in building their regions, in accordance with the slogan that Tulang Bawang Regency has, namely "Sai Bumi Nengah Nyappur".

\section{Implementation of the GSMK Program}

Pressman and Wildavsky (1973), implementation is the process of interaction between determining goals and actions to achieve goals. Basically is the ability to build relationships in the causal chain so that policies can have an impact. The aim of the program must be clearly defined and well understood, resources must be provided, the chain of command must be able to unite and control these resources, the system must communicate effectively and control individuals and organizations involved in carrying out tasks (Parsons, 2008). The implementation concept offered by Pressman and Parson is a very detailed concept explaining that implementation is not just implementing the program, but also about the achievement of goals and even the impact of the implementation of the program itself.

The implementation of the GSMK program, which is the flagship program of the Regent of Tulang Bawang, has been running since 2013. Entering the fifth year, the implementation of the GSMK program continues on the basis of mutual cooperation. Like the background of the formation of the GSMK program which is based on the culture of mutual cooperation in the community. Development that is handed over directly to the village will give rise to equitable development because of the sense of togetherness and belonging by the villagers. Furthermore, the establishment of the village will contribute to the development of the district. The GSMK program was implemented one year before the Central Government established Law Number 06 of 2014 concerning Villages.

This means that the Tulang Bawang District Government has a step faster to find ways to build villages based on the culture of the local community. There was a change in the allocation of funds, of course, before and after the Village Law. Prior to the Village Law, the distribution of funds for the GSMK program was carried out in the form of village fund allocations taken from the Tulang Bawang Regency APBD of Rp 200 million per 
village per year. While following the 2014 Village Law, the budget for the implementation of the GSMK program was raised to Rp.225 million per village per year starting from 2015 since the first phase of development. The budget was sourced from village funds (APBN) and village fund allocations (Tulang Bawang District APBD).

The submission, planning of the use of funds, distribution and use of the funds of the GSMK program was carried out through a hierarchical chain of command and did not change either before or after the Law on Villages. Development planning starts from the results of the Village Development Planning Consultation (Musrenbang Kampung) gathered from the proposals of each citizen or representatives of the people who participated in the meeting. The results of the Village Musrenbang are then proposed to the District Government which will be discussed in the District Musrenbang. At this stage, verification by the Technical Assistant, District Facilitator and the local Camat will lead the District Coordination and Coordination Team to propose the GSMK Program Direct Community Assistance allocation to the Tulang Bawang District Government. The approval of the Regency Government will be set forth in the Decree of the Regent regarding the Implementation of the GSMK Program which is updated annually. The final step in the planning stage is that the village prepares detailed activities and financing details.

The issuance of the Regent's Decree concerning the Implementation of the GSMK Program means the commencement of the disbursement of funds for village infrastructure development, the types of which have been stipulated in the Decree. The GSMK funds will be channeled directly to Pokmas accounts after previously Pokmas submits funds disbursement requests to the District Coordination and Coordination Team (DPMK is approved by the Bupati) facilitated by the Sub-District Head and District Facilitators. Requirements for disbursing funds for the GSMK program are accompanied by different conditions at each stage. Requirements are submitted by Pokmas which are intentionally formed specifically to take care of the GSMK program including fund allocation, construction location, evidence of deliberation and some other evidence of development readiness. Up to this stage, the implementation of the GSMK program has shown the success of the program's objectives, namely initial and democratic. Each planned development comes from the advice of the village community based on the priorities of the village's needs. The community has been forced to and willing to take care of their respective villages.

At the implementation stage of the GSMK program, namely infrastructure development, Pokmas as Chairperson of the Implementing Team Activities lead coordination between communities in development selfhelp. Mutual and participatory cooperation is a great force that is able to realize the completion of the GSMK program implementation to date. Although it has been given stimulants in the form of grants for the GSMK program, it is the sense of togetherness and mutual cooperation that has made the implementation of the GSMK program a sense of ownership of the infrastructure that has been built for the village has also created sincerity in every self-help provided in implementing the GSMK program. There are more important things, whether we realize it or not, about the influence of community leaders who contribute greatly in encouraging the emergence and maintenance of mutual, self-help, and participatory souls from every citizen who establishes these community leaders. The GSMK program which is often said to be similar to the sakai sambayan program is in fact motivated by a large emotional influence from community leaders. For example, the Kagungan Rahayu village which has become a pilot village in the success of the GSMK program, there are Balinese ethnic figures who are highly respected and established.

Kagungan Rahayu village was almost being motivated by Balinese ethnic groups, and led by the Balinese village chief, as if it were a supporting factor that there was a certain tribal influence that made the GSMK program work and there was a reason because certain ethnic groups of the GSMK program were less successful. The thing that needs to be underlined here is that the culture of each tribe is not always different, there are several cultures between the same tribes. For example is mutual cooperation, it is true that Tulang Bawang Regency, which is one of the Regencies in Lampung Province, will prioritize indigenous culture which in the GSMK program promotes a culture of mutual cooperation and is called sakai sambayan in Lampung. But this does not mean other tribes do not make the culture of mutual cooperation as the main element in community life. In the implementation of the GSMK program, there were various tribes living in Kagungan Rahayu Village. However, the ability of village officials to accommodate every element to be willing and participate in the GSMK program is a common thing that proves that leadership capacity in each village is the main thing, to be able to embrace traditional leaders, community leaders, and youth so as to be able to channel the influence and spirit of cooperation

During the process of implementing village infrastructure development, the District Coordination and Coordination Team will periodically report any development developments directly to the Regent. Whereas in the field, there is a District Facilitator, with each sub-district only one person assisted by Pokmas in each village who oversees the development process. The life and growth of the spirit of mutual cooperation between the villagers can be proven in the implementation phase of the GSMK program. There are many types of self-help carried out by the village community. talud or other infrastructure development. During the development 
process, the problems that occur are the weather factors that make the development results not good. Such as the construction of bridges in one of the villages which collapsed due to rain which continued to fall so that the construction of the bridge was considered a failure.

The completion of phase I development will require Pokmas to make accountability reports for phase I which will be one of the requirements for phase II development, as well as for stage III development which must include proof of completion of phase II development through accountability reports. Evaluation will be carried out at each accountability report per stage. This program is accompanied by several agencies appointed and determined by the Regent in the Regent's Decree concerning the Implementation of the GSMK Program, which includes the Assistant for Government and Social Affairs, the Office of Public Works and Spatial Planning, the Community and Village Empowerment Service, the Regional Development Planning Agency, Research and Development. Regional Financial and Asset Management Agency, Inspectorate, Natural Resources and Infrastructure Section, as well as Government and Regional Autonomy. Then for monitoring and evaluation carried out by the District Coordination and Coordination Team together with the District Facilitator, the success ranking is determined based on the coordination meeting agreement. The results of the evaluation will be submitted to the District Coordination Team and Coordination for later stipulated in the Bupati's Decree concerning the Determination of the Best Village in the Implementation of the GSMK Program in Tulang Bawang Regency. Prizes for the best kelurahan I in the form of funds amounting to Rp. 50 million, best II amounting to Rp. 30 million, and best III amounting to Rp. 20 million.

The fund then becomes the right of each winning village. However, many of them use the funds to increase infrastructure development funds the following year, so the amount of development can exceed the minimum target set. During this time, the use of GSMK funds was to build new infrastructure in the village, there were no funds used to maintain existing infrastructure. This proves that the effort to develop village infrastructure is leveled and prioritized to infrastructure that is still $0 \%$ so that every community need for public infrastructure facilities can be met. To realize the goal of sustainable use of the GSMK program, infrastructure maintenance is left entirely to the village community through deliberations coordinated by the local Village Community Working Group using agreed village dues funds or replacement services for the use of facilities and infrastructure that have been built. The principle of democracy in the form of development from, by and for villages has even been fulfilled if each village is able to implement the GSMK program properly and in accordance with the direction, so that the program objectives are achieved and the value of mutual cooperation, participatory, owning, and responsibility are also nurtured and can thrive in the village.

Transparency of receipt of funds, usage up to the remaining cash must be carried out by Pokmas and Village Heads to all village communities. Transparency must be carried out in public places that have been determined by the Tulang Bawang Regency Government in the Regent's Decree concerning the Implementation of the GSMK Program. In practice, transparency is mostly done using a banner media that contains information on the entry, use and remaining funds of the GSMK program installed in front of the Village Hall. Through this method, the public can find out the amount of funds received, used and remaining.

The implementation of the GSMK program in 147 villages from 15 subdistricts in Tulang Bawang Regency which until now has been highlighted by many parties because of its success still leaves the habit of tolerating non-compliance with established regulations. The most obvious and already entrenched thing is the delay in making the results report of the implementation of the GSMK program which means delaying the submission of fundraising for the next stage. The proposed activities that should have been submitted to the District Government in March should be carried out in July and finish at the end of November. However, in practice, the indecisiveness of the District Coordination and Coordination Team and the lack of assistance from the District Facilitators have made some villages absent from their obligations to make previous program implementation reports, thus delaying the subsequent phase of the GSMK program funding. This then has an impact on the implementation of the GSMK program throughout the villages in Tulang Bawang Regency. Tolerance is loosened so that the warning letter given does not in fact make this kind of disease resolved. There are still villages that have not considered important reports so that infrastructure development that should be able to grow more and better becomes delayed and lags behind a more cooperative village.

Overall, the District Coordination and Coordination Team which in this case is the Community Empowerment and Village Empowerment Office considered that the GSMK program had 80\% succeeded in building village infrastructure throughout Tulang Bawang Regency up to the third stage of development in 2016. This can be seen from the processed data DPMK shows that 12 village halls have been built, opening 1 new road (1,400m), 94 drainage $(44,559 \mathrm{~m}), 2$ PAUD buildings, 1 POSYANDU building, 521 culverts $(12,759 \mathrm{~m}), 303$ onderlagh (296,717m), 70 flat concrete roads $(47,150 \mathrm{~m}), 128$ bridges $(1,045 \mathrm{~m}), 6$ lapen roads $(2,945 \mathrm{~m}), 1$ sports podium, 12 village hall rehab, 78 talud $(6,103 \mathrm{~m}), 6$ concrete jeramba poles $(2,223 \mathrm{~m}), 60$ red landfill $(67.108 \mathrm{~m})$, and 3 paving blocks $(2.710 \mathrm{~m})$. Satisfactory results in the five-year development period of 147 villages in the entire Tulang Bawang Regency. Of course there are many supporting factors for this success, and the biggest supporting factor is of course the village community itself. 


\section{The Importance of Cultural Approaches in the Implementation of the GSMK Program}

The GSMK program is intended to encourage the development of development programs from, by and for the community by utilizing the unique social potentials and institutions that exist in the community. Mutual cooperation, becoming a typical social institution chosen to inspire the GSMK program, the potential that deserves to be empowered becomes a great force to realize an independent village building on the basis of selfreliance and sustainability because of a sense of belonging. There are things that need to be learned from the success of this GSMK program, namely the importance of upholding the cultural values held by the community in a village. Departing the goals of development by spurring the growth of the values of community life that has become a living culture of the community itself will be able to make success for the implementation of a program.

The use of culture for the implementation of a policy, of course, cannot be equated between one region and another, not for every other policy. Each region has its own characteristics and culture, so that the use of culture can be used as a medium of empowerment as well as appropriate policy implementation, in accordance with the social institutions of policy objectives, and can be easily accepted by policy objectives. As with different policies, it cannot impose a culture that is the same for all types of policies. Although the objectives of these policies may be intended to be empowered, not all policy objectives can be achieved using the same cultural approach. The use of a cultural approach to policy implementation is not as easy as it looks. Understanding of social conditions and good community culture is necessary, because homogeneity can be a force but can also be a major threat to policy implementation.

The importance of a cultural approach to policy implementation is to realize true democracy. Based on each policy to the real needs needed by the community, increasing the active role of the community in realizing policy implementation, maintaining the values and culture of society in every aspect of life, and marginalizing the policy implementation stigma by the government through structural, procedural and even political approaches that are not understood by the public general so that the acceptance and usefulness are very low. These types of approaches are always seen as the needs of the authorities, this is because they come from the point of view of the government and stakeholders. Not from the point of view of the community, so that the needs of the community are often not met due to wrong targets.

Cultural approaches to policy implementation are being implemented by many local governments or agencies in Indonesia. Learning from the success of several regions that first implemented and succeeded in implementing policies using a cultural approach, many have now adopted a cultural approach to policy implementation. The cultural approach is considered as the latest innovation in the realm of policy implementation. Society as the target of the policy making itself starts to be involved also as the plan maker, supervisor, implementer, and even evaluator. Management capacity on a large scale for the size of a public policy is certainly not owned by the community. However, the management of public policy on a large scale can be simplified in accordance with the ability to understand the target community so that it can be accepted and understood well. The impact is that, consciously or unconsciously, the community has learned how to advance themselves and their own environment, through self-help, cooperation, and environmental unity.

The cultural approach is more directed at bringing forth cultural values that actually exist in the community and the community. Using a cultural approach to policy implementation will also flourish the soul of having what they have planned and made. This awareness will create a situation to continue to keep things or things they feel belong to themselves. The benefits will last a long time, so that later it will create a welfare impact in other sectors for the community itself. For example, is the implementation of the GSMK program that uses a mutual cultural approach, the community has a sense of mutual ownership of the infrastructure they have built. People are given the opportunity to determine what they will build, so that at this time various infrastructures have been used according to their use. However, if we look at the impact on other sectors, the construction of road infrastructure, for example, has shown that road infrastructure development has made POSYANDU activities run smoothly, crowded and exceeding targets. This will have an impact on the health of infants and mothers who are increasing, so that there are no more people who are malnourished or other health problems. The correlation with road infrastructure is a matter of interest and willingness. If things turn around, the road conditions are bad, then POSYANDU activities are likely not going to run as smoothly as they are now.

Other impacts of infrastructure development in villages in Tulang Bawang Regency are likely to emerge. Actually the long-term impact of the GSMK program is not only to foster community self-reliance, but also to advance other sectors through adequate infrastructure. This is the reason the GSMK program focuses on infrastructure development. Development of other sectors, development of human resources for example, is still the duty of all parties in Tulang Bawang Regency. The main problem has been opened, then the development relay that is pro active and touches directly to the community must be continued to realize development in all sectors of life. 


\section{IV.CONCLUSION}

Based on the results of the discussions that have been described, the implementation of the GSMK program is based on the value of mutual cooperation which in local terms Lampung is called sakai sambayan. Sakai sambayan, there is a broad understanding, such as mutual cooperation, help to help, tolerance to others and to others both morally and materially at times of pleasure and distress.

This value provides a spirit in the implementation of the GSMK program in Tulang Bawang Regency. The GSMK program is a movement carried out by, from, and for the people of Tulang Bawang Regency to do good together in an effort to accelerate infrastructure development in 147 villages simultaneously throughout the Tulang Bawang Regency with a budget sourced from non-government organizations, private parties from each village and Bantuan Langsung Masyarakat (BLM) of the APBD of Tulang Bawang Regency. This program is considered quite successful by many people, the innovation of cultural approaches in the implementation of policies makes it an alternative so that policies can be successful and goals can be achieved.

\section{References}

Abdullah, Irwan. 2010. Konstruksi dan Reproduksi Kebudayaan. Yogyakarta. Pustaka Pelajar.

Anderson, J.E. 1979. Public Policy Making.New York. Holt, Renihart and Winston.

Dunn, William N. 2000, (1981). Public Policy Analysis: An Introduction. New Jersey: Perason Education. Edisi bahasa Indonesia diterjemahkan dari edisi kedua (1994) diterbitkan sejak 1998.Dengan judul pengantar analisis kebijakan publik.Yogyakarta.Gadjah Mada University Press.

Ismany, M.I. 2002.Prinsip-prinsip Perumusan Kebijaksanaan Negara.Jakarta. Bumi Aksara.

Moleong, L.J. 2000.MetodologiPenelitian Kualitatif. Bandung. Remaja Rosdakarya.

Nugroho, Riant. 2008. Public Policy. Jakarta. PT. Elex Media Komputindo.

Parsons, Wayne. 2008. Public Policy (Pengantar Teori dan Praktek Analisis Kebijakan). Jakarta. Prenada Media Group.

Putra, F. 2003. Paradigma Kritis Dalam Studi Kebijakan Publik. Yogyakarta. Pustaka Pelajar.

Purwanto, Erwan Agus dan Dyah Ratih Sulistyastuti. 2012. Implementasi Kebijakan Publik: Konsep dan Aplikasinya di Indonesia. Yogyakarta.Penerbit Gava Media.

Subarsono, AG. 2005. Analisis Kebijakan Publik, konsep,teori dan aplikasi. Yogyakarta. Pustaka Pelajar.

Sugiyono. 2003. Metode Penelitian Administrasi. Bandung. PT. Alfabeta.

Tarigan, Robinson. 2005. Perencanaan Pembangunan Wilayah. Jakarta. PT. Bumi Aksara.

Wahab,S.A. 2000. Analisis Kebijaksanaan dari Formulasi ke Implementasi Kebijaksanaan Negara.Jakarta. Bumi Aksara.

Wahab, SA. 2010. Analisis Kebijaksanaan Edisi Kedua dari Formulasi ke Implementasi Kebijaksanaan Negara. Jakarta. Bumi Aksara.

Winarno, Budi. 2002. Teori dan Proses Kebijakan Publik. Yogyakarta.Media Pressindo. 